\title{
KINERJA KEUANGAN SEBAGAI INTERVENING \\ ANTARA INCOME SMOOTHING DAN ECONOMIC VALUE ADDED DENGAN NILAI PERUSAHAAN
}

\author{
Ainun Jariah \\ STIE Widya Gama Lumajang, anjar040820@,gmail.com
}

\begin{abstract}
Abstrak
Nilai perusahaan merupakan suatu hal yang penting bagi seorang manajer maupun bagi seorang investor. Nilai perusahaan merupakan persepsi investor terhadap perusahaan, yang sering dikaitkan dengan harga saham. Jika seorang manajer mampu untuk meningkatkan nilai perusahaan maka manajer tersebut telah menunjukkan kinerja baik bagi perusahaan. Sedangkan bagi investor peningkatan nilai perusahaan merupakan suatu persepsi yang baik terhadap perusahaan. Penelitian ini bertujuan untuk membuktikan pengaruh income smoothing dan economic value added secara langsung dan tidak langsung, maupun secara parsial dan simultan terhadap kinerja perusahaan dan nilai perusahaan manufaktur sektor barang konsumsi yang terdaftar di Bursa Efek Indonesia. Jumlah sampel 22 perusahaan yang aktif mempublikasikan laporan keuangannya selama periode penelitian. Teknik analisis data menggunakan model analisis jalur melakukan pengujian subtruktur pertama dan substruktur kedua. Pengujian hipotesis dilakukan secara langsung dan tidak langsung. Hasil penelitian menunjukkan bahwa baik secara parsial dan simultan income smoothing dan economic value added tidak berpengaruh secara signifikan terhadap nilai perusahaan maupun kinerja keuangan. Pengaruhnya melalui kinerja keuangan menunjukkan pengaruh yang sangat lemah dan tidak signifikan. Diperoleh nilai koefisien korelasi berganda (R) sebesar 0,207 dengan signifikansi 0,250 yang berarti terbukti terdapat hubungan dengan nilai perusahaan secara tidak signifikan. Sedangkan nilai koefisien determinasi ( $\mathrm{R}$ square) sebesar 0,043 atau 4,3\% berarti income smoothing dan economic value added mampu menjelaskan pengaruhnya terhadap variabel nilai perusahaan secara bersama-sama sebesar 4,3\% dan sisanya sebesar 95,7\% dijelaskan oleh variabel lainnya.
\end{abstract}

Kata Kunci: Income Smoothing, Economic Value Added, Kinerja Keuangan, Nilai Perusahaan

\begin{abstract}
Corporate value is an important thing for a manager or an investor. The value of a firm is an investor's perception of the company, which is often associated with stock prices. If a manager is able to increase a company's value then the manager has performed well for the company. As for investors, the increase in corporate value is a good perception of the company. This study aims to prove the effect of income smoothing and economic value added directly and indirectly, or partially and simultaneously to the performance of the company and the value of consumer goods manufacturing sector companies listed on the Indonesia Stock Exchange. The number of samples of 22 companies that actively publish their financial statements during the study period. Data analysis techniques using path analysis model to test the first substructure and second substructure. Hypothesis testing is done directly and indirectly. The results showed that both partially and simultaneously income smoothing and economic value added had no significant effect on firm value or financial performance. Its influence through financial performance shows a very weak and insignificant effect. The value of multiple correlation coefficient $(R)$ is 0.207 with significance of 0.250 which means that there is no significant correlation with firm value. While the value of coefficient of determination ( $R$ square) of 0.043 or $4.3 \%$ means income smoothing and economic value added able to explain the effect on corporate value variable together $4.3 \%$ and the rest of $95.7 \%$ explained by other variables.
\end{abstract}

Keywords: Income Smoothing, Economic Value Added, Financial Performance, Value of Corporate 


\section{PENDAHULUAN}

Pendirian sebuah perusahaan memiliki beberapa tujuan yang jelas, yang pertama adalah untuk mencapai keuntungan maksimal atau laba yang sebesar-besarnya. Tujuan yang kedua adalah ingin memakmurkan pemilik perusahaan atau para pemilik saham. sedangkan tujuan yang ketiga adalah memaksimalkan nilai perusahaan yang tercermin pada harga sahamnya (Martono dan Agus Harjito, 2005:2).(Jariah, 2012)

Hermuningsih dan Wardani (2009) mengatakan nilai perusahaan merupakan persepsi investor terhadap perusahaan, yang sering dikaitkan dengan harga saham. Pujiati dan Widanar (2009) juga menyatakan bahwa harga pasar saham perusahaan merupakan suatu cerminan penilaian investor secara keseluruhan atas setiap ekuitas yang dimiliki. Selain itu, harga pasar saham menunjukkan penilaian sentral diseluruh pelaku pasar, dan bertindak sebagai barometer kinerja manajemen perusahaan. (Nawangsih, 2017)Nilai perusahaan ini merupakan suatu hal yang penting bagi seorang manajer maupun bagi seorang investor. Bagi seorang manajer nilai perusahaan merupakan suatu tolak ukur atas prestasi kerja yang telah dicapainya.(Ato'Illah, 2014) Jika seorang manajer mampu untuk meningkatkan nilai perusahaan maka manajer tersebut telah menunjukkan kinerja baik bagi perusahaan. Selain itu, secara tidak langsung manajer ini telah mampu untuk meningkatkan kemakmuran bagi pemegang saham yang merupakan tujuan perusahaan. Sedangkan bagi investor peningkatan nilai perusahaan merupakan suatu persepsi yang baik terhadap perusahaan.(Ajanthan, 2013)

Pada umumnya setiap perusahaan selalu berusaha untuk memaksimumkan keuntungan yang diperolehnya. Berbagai strategi diterapkan guna mencapai tujuan tersebut. Perusahaan akan selalu menjaga agar kinerjanya terlihat baik dimata para stakeholdernya. (Paramita, 2012)Namun pada kenyataannya, perusahaan seringkali dihadapkan pada berbagai kendala yang bisa menyebabkan penurunan kinerja bahkan kesulitan keuangan hingga akhirnya bangkrut. Dan tentu saja perusahaan akan berusaha untuk menutupi kondisi tidak sehat tersebut dari para stakeholdernya. Salah satunya adalah dengan cara earning management (manajemen laba). (Robustin, 2015)Manajemen laba adalah campur tangan dalam proses penyusunan pelaporan keuangan eksternal, dengan tujuan untuk memperoleh keuntungan pribadi (Schipper dalam; Sulistyanto, 2008). Manajemen laba dapat mengurangi kredibilitas laporan keuangan apabila digunakan untuk pengambilan keputusan, karena earning management merupakan suatu bentuk manipulasi atas laporan keuangan yang menjadi sasaran komunikasi antara manajer dan pihak eksternal perusahaan (Surifah, 1999; dalam Lestari dan Pamudji, 2013).(Kumar, 2004)(Irwanto, 2017)

Menurut Aji dan Mita (2010), teknik - teknik pengelolaan laba yang oportunistik seringkali menggunakan teknik perataan laba (income smoothing). Praktik perataan laba disebabkan adanya motivasi manajemen untuk mengurangi fluktuasi laba yang dilaporkan. Manajemen memilih untuk menjaga nilai laba yang stabil 
dibandingkan nilai laba yang cenderung bergejolak (volatile), sehingga manajemen akan menaikkan laba yang dilaporkan jika jumlah laba yang sebenarnya menurun dari laba tahun sebelumnya. (Iridiana, 2016)Sebaliknya manajemen akan memilih untuk menurunkan laba yang dilaporkan jika laba yang sebenarnya meningkat dibandingkan laba tahun sebelumnya (Novita, 2009). Laba yang rata dari tahun ke tahun sangat disukai oleh manajemen dan investor, karena laba yang rata mengindikasikan bahwa perusahaan tersebut kuat dan stabil (Atik,2008).(Ermawati, 2017)

Berbagai permasalahan yang timbul dalam pengukuran kinerja keuangan berdasarkan data akuntansi akan diatasi dengan pengukuran kinerja keuangan berdasarkan nilai (value based). (Budiwati \& Jariah, 2014)Pengukuran tersebut dapat dijadikan dasar bagi manajemen perusahaan dalam pengelolaan modalnya, rencana pembiayaan, wahana komunikasi dengan pemegang saham serta dapat digunakan sebagai dasar dalam menentukan insentif bagi karyawan (Amin Widjaya : 2001). (Lukiana, 2014)Dengan value based sebagai alat pengukur kinerja perusahaan, manajemen dituntut untuk meningkatkan nilai perusahaan. Pengukuran value added yang telah banyak dikemukakan adalah Economic Value Added (EVA) (Amin Widjaya : 2001).(Ifa, 2017)

Economic Value Added (EVA) atau disebut juga dengan nilai tambah ekonomis (NITAMI) diartikan sebagai suatu konsep yang dilandasi oleh pemikiran bahwa dalam pengukuran laba operasi perusahaan harus dengan adil mempertimbangkan harapan - harapan setiap penyedia dana (kreditur dan pemegang saham). Derajat keadilannya dinyatakan dengan ukuran tertimbang dan struktur modal yang ada (Widayanto, 1993:51). Menurut Young dan O'Byrne (2001: 18) EVA merupakan alat komukasi yang efektif baik untuk penciptaan nilai yang dapat dijangkau oleh manajer lini yang akhirnya mendorong kinerja perusahaan dan untuk menghubungkan dengan pasar modal.(Yatminiwati, 2017)

Beberapa penelitian yang pernah dilakukan peneliti sebelumnya, yaitu penelitian yang dilakukan Andrie Putra \& Royhisar Martahan Simanungkalit (2014) dengan judul The Impact of Implementation Good Corporate Governance to Firm Value (Evidence from Indonesia Public Banking Sector). Variabel penelitian good corporate governance, earning management, financial report, firm performance, firm value, dengan metode path analysis. Hasil penelitian menunjukkan bahwa GCG berpengaruh terhadap kinerja perbankan, earning management berpengaruh terhadap kinerja perbankan, financial report disclosure tidak berpengaruh terhadap kinerja perbankan, GCG tidak memiliki pengaruh terhadap nilai perusahaan, tetapi jika GCG digabung dengan earning management akan berpengaruh terhadap nilai perusahaan. Penelitian yang dilakukan oleh Mohammad Reza Shourvarzi and Sahar Sadeddin (2011) dengan judul Analysis of The Predictive Ability of The Components of Economic Value added in Predicting Next Period's Operating Profit: Evidence From Iran. Variabel penelitian economic value added, return on assets, cost of capital, amount of capital, net operating after tax, dan operating profit, dengan metode simple regression. Hasil 
penelitian menunjukkan bahwa return on asset, amount of capital, dan net operating after tax dapat memprediksi laba operasi periode berikutnya, biaya modal tidak dapat memprediksi laba operasi periode berikutnya. Penelitian yang dilakukan Andrie Putra \& Royhisar Martahan Simanungkalit (2014) dengan judul The Impact of Implementation Good Corporate Governance to Firm Value (Evidence from Indonesia Public Banking Sector). Variabel penelitian good corporate governance, earning management, financial report, firm performance, firm value, dengan metode path analysis. Hasil penelitian menunjukkan bahwa GCG berpengaruh terhadap kinerja perbankan, earning management berpengaruh terhadap kinerja perbankan, financial report disclosure tidak berpengaruh terhadap kinerja perbankan, GCG tidak memiliki pengaruh terhadap nilai perusahaan, tetapi jika GCG digabung dengan earning management akan berpengaruh terhadap nilai perusahaan.(Fauziah \& Psikolingui, n.d.)

Penelitian yang berkesinambungan mengenai nilai perusahaan dan kinerja keuangan yang dipengaruhi oleh income smoothing dan economic value added. Oleh karena itu tujuan penelitian ini adalah:

a. Untuk mendapatkan bukti empiris bahwa income smoothing dan economic value added memiliki pengaruh yang signifikan secara parsial terhadap kinerja keuangan.

b. Untuk mendapatkan bukti empiris bahwa income smoothing dan economic value added memiliki pengaruh yang signifikan secara simultan terhadap kinerja keuangan.

c. Untuk mendapatkan bukti empiris bahwa income smoothing dan economic value added memiliki pengaruh yang signifikan secara parsial terhadap nilai perusahaan.

d. Untuk mendapatkan bukti empiris bahwa income smoothing dan economic value added memiliki pengaruh yang signifikan secara simultan terhadap nilai perusahaan.

e. Untuk mendapatkan bukti empiris bahwa kinerja keuangan memiliki hubungan yang signifikan terhadap nilai perusahaan.

f. Untuk mendapatkan bukti empiris bahwa income smoothing dan economic value added memiliki pengaruh yang signifikan secara parsial terhadap nilai perusahaan melalui kinerja keuangan.

g. Untuk mendapatkan bukti empiris bahwa income smoothing dan economic value added memiliki pengaruh yang signifikan secara simultan terhadap nilai perusahaan melalui kinerja keuangan.

\section{METODOLOGI}

\section{Rancangan Penelitian}

Penelitian ini termasuk jenis penelitian survei (survey research) yaitu penelitian yang tidak melakukan perubahan atau tidak ada perlakuan khusus terhadap variabel-variabel yang diteliti (non experimental). Tujuan penelitian ini bersifat eksplanatori (explanatory research) dan prediksi dimana penelitian eksplanatori merupakan jenis penelitian yang menjelaskan hubungan kausal antara satu 
variabel dengan variabel lainnya melalui pengujian hipotesis. Berdasarkan sifatnya, penelitian ini bersifat eksploratif karena pengujian lebih lanjut atas suatu penelitian.

\section{Obyek Penelitian}

Obyek penelitian ini adalah income smoothing, economic value added, kinerja keuangan, dan nilai perusahaan. Penelitian ini dilakukan terhadap perusahaan manufaktur sektor barang konsumsi yang terdaftar di Bursa Efek Indonesia periode 2014 - 2016. Alasan dipilihnya perusahaan manufaktur yang terdaftar di Bursa Efek Indonesia sebagai lokasi penelitian karena perusahaan tersebut adalah perusahaan terbuka sehingga peneliti lebih mudah untuk memperoleh data keuangan yang diperlukan.

\section{Sumber dan Jenis Data}

Jenis data yang digunakan dalam penelitian ini adalah data sekunder berupa laporan keuangan yang terdiri dari: neraca dan laporan laba rugi dengan mengakses situs dari Bursa Efek Indonesia. Sumber data yang digunakan dalam penelitian ini adalah sumber data internal karena data diperoleh dari dalam perusahaan. Unit analisis dalam penelitian ini adalah perusahaan yang berupa laporan keuangan, yang terdiri dari: neraca dan laporan laba rugi.

\section{Populasi dan Teknik Pengambilan Sampel}

Populasi dalam penelitian ini adalah perusahaan manufaktur yang terdaftar di Bursa Efek Indonesia, periode 2014 - 2016, yang keseluruhan berjumlah 72 . Pengambilan sampel dilakukan dengan metode purposive sampling. Kriteria perusahaan manufaktur yang dapat dijadikan sampel penelitian ini adalah:

a. Perusahaan manufaktur yang listed di Bursa Efek Indonesia pada periode penelitian.

b. Perusahaan manufaktur yang sudah berdiri dan terdaftar dalam Bursa Efek Indonesia minimal sejak tahun 2012.

c. Perusahaan yang pada periode penelitian tidak melaksanakan akuisisi dan merger.

d. Laporan keuangan perusahaan menggunakan satuan uang yang sama selama periode penelitian.

\section{Teknik Analisis Data}

Teknik analisis data dalam penelitian ini akan dilakukan dengan menggunakan model analisis jalur dengan aplikasi SPSS. Dengan mempertimbangkan pula uji asumsi klasik/pengujian asumsi dasar untuk memenuhi kaidah-kaidah dalam model regresi yang telah dirancang dalam penelitian ini. Untuk pengujian hipotesis menggunakan analisis jalur dengan tahap-tahap penyelesaian sebagai berikut:

a. Menentukan model diagram jalur berdasarkan paradigma hubungan variabel.

b. Menentukan hipotesis penelitian.

c. Pengolahan data dengan SPSS untuk substruktur 1 .

d. Pengolahan data dengan SPSS untuk substruktur 2 . 
e. Melakukan analisis output regresi.

f. Menguji ketepatan model yang dihasilkan.

g. Menentukan model persamaan analisis regresi untuk dua jalur.

\section{HASIL DAN PEMBAHASAN}

\section{Hasil Penelitian}

Perusahaan manufaktur yang dijadikan populasi adalah perusahaan manufaktur sektor industri barang konsumsi yang terdaftar di Bursa Efek Indonesia sampai dengan tahun 2016. Setelah dilakukan pengambilan sampel dengan menggunakan kriteria tertentu, maka dari 37 perusahaan hanya 22 perusahaan yang bisa dijadikan sampel penelitian.

Tabel 1. Perusahaan Manufaktur yang Menjadi Sampel Penelitian

\begin{tabular}{|c|c|c|c|}
\hline NO & KODE & NAMA PERUSAHAAN & $\begin{array}{l}\text { LAP. KEUANGAN YANG } \\
\text { DIGUNAKAN }\end{array}$ \\
\hline 1 & ALTO & PT. TRI BANYAN TIRTA, Tbk. & 31 DESEMBER $2014-2016$ \\
\hline 2 & CEKA & PT. WILMAR CAHAYA INDONESIA, Tbk. & 31 DESEMBER 2014 - 2016 \\
\hline 3 & DLTA & PT. DELTA JAKARTA, Tbk. & 31 DESEMBER $2014-2016$ \\
\hline 4 & ICBP & PT. INDOFOOD CBP SUKSES MAKMUR, Tbk. & 31 DESEMBER $2014-2016$ \\
\hline 5 & INDF & PT. INDOFOOD SUKSES MAKMUR, Tbk. & 31 DESEMBER $2014-2016$ \\
\hline 6 & GGRM & PT. GUDANG GARAM, Tbk. & 31 DESEMBER 2014 - 2016 \\
\hline 7 & HMSP & PT. HANJAYA MANDALA SAMPOERNA, Tbk. & 31 DESEMBER $2014-2016$ \\
\hline 8 & WIIM & PT. WISMILAK INTI MAKMUR, Tbk. & 31 DESEMBER $2014-2016$ \\
\hline 9 & DVLA & PT. DARYA VARIA LABORATORIA, Tbk. & 31 DESEMBER $2014-2016$ \\
\hline 10 & INAF & PT. INDOFARMA, Tbk. & 31 DESEMBER $2014-2016$ \\
\hline 11 & KLBF & PT. KALBE FARMA, Tbk. & 31 DESEMBER $2014-2016$ \\
\hline 12 & MERK & PT. MERCK, Tbk. & 31 DESEMBER $2014-2016$ \\
\hline 13 & PYFA & PT. PYRIDAM FARMA, Tbk. & 31 DESEMBER 2014 - 2016 \\
\hline 14 & SQBB & PT.TAISHO PHARMACEUTICAL INDONESIA, Tbk. & 31 DESEMBER $2014-2016$ \\
\hline 15 & TSPC & PT. TEMPO SCAN PASIFIC, Tbk. & 31 DESEMBER $2014-2016$ \\
\hline 16 & ADES & PT. AKASHA WIRA INTERNAL, Tbk. & 31 DESEMBER $2014-2016$ \\
\hline 17 & MBTO & PT. MARTINA BERTO, Tbk. & 31 DESEMBER $2014-2016$ \\
\hline 18 & MRAT & PT. MUSTIKA RATU, Tbk. & 31 DESEMBER $2014-2016$ \\
\hline 19 & TCID & PT. MANDOM INDONESIA, Tbk. & 31 DESEMBER $2014-2016$ \\
\hline 20 & $\mathrm{KICI}$ & PT. KEDAUNG INDAG CAN, Tbk. & 31 DESEMBER $2014-2016$ \\
\hline 21 & LMPI & PT. LANGGENG MAKMUR INDUSTRY, Tbk. & 31 DESEMBER $2014-2016$ \\
\hline 22 & CINT & PT. CHITOSE INTERNASIONAL, Tbk. & 31 DESEMBER $2014-2016$ \\
\hline
\end{tabular}

Sumber data: www.sahamok.com/perusahaan-manufaktur-di-bei/manufaktur

Berdasarkan sampel yang telah dipilih, berikut disajikan hasil perhitungan masing-masing variabel pada 22 perusahaan manufaktur sektor barang konsumsi.

Tabel 2. Hasil Perhitungan Income Smoothing

\begin{tabular}{|c|c|c|c|c|}
\hline NO & KODE & $\mathbf{2 0 1 4}$ & $\mathbf{2 0 1 5}$ & $\mathbf{2 0 1 6}$ \\
\hline 1 & PERUSAHAAN & 0,14 & 0,46 & 0,41 \\
2 & ALTO & 0,02 & 0,30 & 0,23 \\
3 & CEKA & 0,16 & 0,07 & 0,83 \\
4 & DLTA & 0,06 & 0,23 & 0,26 \\
5 & ICBP & 0,20 & 2,50 & 0,60 \\
6 & INDF & 0,10 & 0,20 & 0,04 \\
7 & GGRM & 0,11 & 0,02 & 0,37 \\
8 & HMSP & 0,27 & 0,26 & 0,34 \\
9 & WIIM & 20,99 & 0,13 & 0,30 \\
10 & DVLA & 1,26 & 0,02 & 0,45 \\
11 & INAF & 0,11 & 0,12 & 0,20 \\
12 & KLBF & 0,10 & 0,32 & 0,22 \\
13 & MERK & 0,12 & 2,31 \\
14 & PYFA & 0,22 & 0,10 & 0,29 \\
\hline
\end{tabular}




\begin{tabular}{|l|c|c|c|c|}
\hline 15 & TSPC & 0,08 & 0,08 & 0,02 \\
16 & ADES & 0,32 & 0,02 & 0,11 \\
17 & MBTO & 0,44 & 0,73 & 0,56 \\
18 & MRAT & 0,18 & 0,95 & 0,08 \\
19 & TCID & 0,05 & 55,36 & 1,80 \\
20 & KICI & 0,69 & 1,58 & 1,75 \\
21 & LMPI & 0,08 & 0,04 & 0,07 \\
22 & CINT & 3,58 & 0,13 & 0,73 \\
\hline
\end{tabular}

Sumber data: Data Laporan Keuangan pada Bursa Efek Indonesia diolah, 2017

Tabel 3. Hasil Perhitungan Economic Value Added

\begin{tabular}{|c|c|c|c|c|}
\hline NO & KODE & $\mathbf{2 0 1 4}$ & $\mathbf{2 0 1 5}$ & $\mathbf{2 0 1 6}$ \\
\hline 1 & PERUSAHAAN & -387.539 .482 .354 & -400.559 .186 .153 & -353.298 .339 .284 \\
2 & ALTO & -311.619 .917 .694 & -300.414 .741 .520 & -152.828 .664 .740 \\
3 & CEKA & 100.666 .448 .618 & 34.780 .354 .277 & 94.328 .127 .248 \\
4 & DLTA & -3.523 .429 .879 .528 & -3.384 .522 .978 .867 & -3.166 .363 .360 .395 \\
5 & ICBP & -16.042 .788 .808 .368 & -17.829 .377 .163 .605 & -14.588 .546 .809 .005 \\
6 & INDF & -8.451 .762 .846 .580 & -8.345 .761 .290 .578 & -7.735 .161 .645 .795 \\
7 & GGRM & 3.075 .975 .762 .818 & 5.107 .693 .156 .965 & 5.795 .389 .360 .578 \\
8 & HMSP & -309.778 .913 .723 & -281.419 .113 .359 & -434.380 .082 .811 \\
9 & WIIM & -348.006 .775 .878 & -372.328 .885 .600 & -360.882 .727 .762 \\
10 & DVLA & -413.146 .982 .914 & -438.977 .871 .749 & -457.623 .606 .495 \\
11 & INAF & 40.143 .463 .356 & -177.026 .558 .547 & 52.791 .407 .378 \\
12 & KLBF & 38.721 .763 .870 & 2.155 .427 .012 & 10.442 .705 .473 \\
13 & MERK & -65.390 .545 .123 & -63.888 .044 .202 & -64.644 .194 .087 \\
14 & PYFA & 84.811 .041 .493 & 59.344 .706 .001 & 66.356 .832 .024 \\
15 & SQBB & -619.909 .888 .254 & -922.013 .863 .928 & -936.181 .706 .273 \\
16 & TSPC & -437.847 .958 .207 & -428.392 .928 .123 & -404.511 .678 .075 \\
17 & ADES & -188.931 .664 .679 & -222.980 .365 .326 & -211.092 .898 .104 \\
18 & MBTO & -118.841 .694 .011 & -126.135 .927 .599 & -126.818 .401 .538 \\
19 & MRAT & -288.553 .320 .543 & -160.525 .937 .759 & -246.982 .445 .856 \\
20 & TCID & -65.659 .039 .464 & 84.466 .002 .500 & -75.231 .122 .525 \\
21 & KICI & -435.751 .685 .759 & -436.445 .035 .845 & -437.501 .529 .195 \\
22 & LMPI & -109.421 .888 .454 & -105.463 .413 .609 & 117.882 .163 .203 \\
\hline
\end{tabular}

Sumber data: Data Laporan Keuangan pada Bursa Efek Indonesia diolah, 2017

Tabel 4. Hasil Perhitungan Kinerja Keuangan

\begin{tabular}{|c|c|c|c|c|}
\hline NO & KODE & $\mathbf{2 0 1 4}$ & $\mathbf{2 0 1 5}$ & $\mathbf{2 0 1 6}$ \\
\hline 1 & PERUSAHAAN & $-0,01$ & $-0,02$ & 0,18 \\
2 & ALTO & 0,03 & 0,07 & 0,21 \\
3 & CEKA & 0,29 & 0,18 & 0,13 \\
4 & DLTA & 0,10 & 0,11 & 0,06 \\
5 & ICBP & 0,05 & 0,04 & 0,11 \\
6 & INDF & 0,09 & 0,10 & 0,08 \\
7 & GGRM & 0,36 & 0,27 & 0,10 \\
8 & HMSP & 0,08 & 0,10 & $-0,01$ \\
9 & WIIM & 0,07 & 0,08 & 0,15 \\
10 & DVLA & 0,00 & 0,00 & 0,21 \\
11 & INAF & 0,15 & 0,03 \\
12 & KLBF & 0,17 & 0,22 & 0,34 \\
13 & MERK & 0,25 & 0,02 & 0,08 \\
14 & PYFA & 0,02 & 0,32 & 0,07 \\
15 & SQBB & 0,36 & 0,08 & 0,01 \\
16 & TSPC & 0,10 & 0,05 & $-0,01$ \\
17 & ADES & 0,06 & $-0,02$ & 0,07 \\
18 & MBTO & 0,00 & 0,00 & 0,00 \\
19 & MRAT & 0,01 & 0,26 & 0,01 \\
20 & TCID & 0,09 & $-0,10$ & 0,05 \\
21 & KICI & 0,05 & 0,01 & 0,08 \\
22 & LMPI & 0,00 & 0,07 & 201 \\
\hline
\end{tabular}

Sumber data: Data Laporan Keuangan pada Bursa Efek Indonesia diolah 2017 
Tabel 5. Hasil Perhitungan Nilai Perusahaan

\begin{tabular}{|c|c|c|c|c|}
\hline NO & $\begin{array}{c}\text { KODE } \\
\text { PERUSAHAAN }\end{array}$ & 2014 & 2015 & 2016 \\
\hline 1 & ALTO & 1,44 & 1,40 & 1,50 \\
\hline 2 & CEKA & 0,83 & 0,63 & 0,90 \\
\hline 3 & DLTA & 0,01 & 4,90 & 3,95 \\
\hline 4 & ICBP & 5,08 & 4,79 & 2,70 \\
\hline 5 & INDF & 1,44 & 1,05 & 1,58 \\
\hline 6 & GGRM & 3,51 & 2,78 & 3,11 \\
\hline 7 & HMSP & 22,29 & 13,66 & 0,52 \\
\hline 8 & WIIM & 1,54 & 0,96 & 0,93 \\
\hline 9 & DVLA & 1,97 & 1,50 & 1,82 \\
\hline 10 & INAF & 1,75 & 0,88 & 25,19 \\
\hline 11 & KLBF & 8,74 & 5,66 & 5,70 \\
\hline 12 & MERK & 6,47 & 0,32 & 0,35 \\
\hline 13 & PYFA & 0,75 & 0,59 & 1,01 \\
\hline 14 & SQBB & 0,26 & 0,27 & 0,27 \\
\hline 15 & TSPC & 3,12 & 1,28 & 1,91 \\
\hline 16 & ADES & 0,70 & 0,58 & 1,53 \\
\hline 17 & MBTO & 0,47 & 0,34 & 0,45 \\
\hline 18 & MRAT & 0,39 & 0,24 & 0,24 \\
\hline 19 & TCID & 0,75 & 1,93 & 1,41 \\
\hline 20 & KICI & 0,47 & 0,37 & 0,19 \\
\hline 21 & LMPI & 0,44 & 0,28 & 0,33 \\
\hline 22 & CINT & 1,24 & 1,07 & 0,97 \\
\hline
\end{tabular}

Sumber data: Data Laporan Keuangan pada Bursa Efek Indonesia diolah, 2017

\section{Hasil Pengujian Asumsi Klasik}

\section{Hasil Uji Normalitas}

Pengujian normalitas dilakukan terhadap residual regresi. Pengujian dilakukan dengan menggunakan grafik P-P Plot. Hasil pengujian normalitas data menunjukkan adanya pola grafik yang normal dimana titik-titik berada tidak jauh dari garis diagonal, hal ini berarti bahwa model regresi tersebut sudah berdistribusi normal.

\section{Hasil Uji Multikolinearitas}

Suatu variabel menunjukkan gejala multikolinieritas bisa dilihat dari nilai VIF (Variance Inflation Factor) yang tinggi pada variabel-variabel bebas suatu model regresi. Nilai VIF yang lebih besar dari 10 menunjukkan adanya gejala multikolinieritas dalam model regresi. Hasil pengujian menunjukkan bahwa semua variabel yang digunakan sebagai prediktor model regresi menunjukkan nilai VIF yang cukup kecil, dimana semuanya berada di bawah 10 dan nilai tollerance lebih dari 0,1 . Hal ini berarti bahwa variabel bebas yang digunakan dalam penelitian tidak menunjukkan adanya gejala multikolinieritas.

\section{Hasil Uji Autokorelasi}

Penggunaan uji autokorelasi adalah untuk melihat apakah ada hubungan linier antara error serangkaian observasi yang diurutkan menurut waktu (data time series). Berdasarkan hasil uji, maka dapat disimpulkan model regresi yang dihasilkan pada penelitian ini bebas dari autokorelasi. 


\section{Hasil Heteroskedastisitas}

Pengujian heteroskedastisitas dilakukan dengan menggunakan Scatter Plot. Jika tidak terdapat variabel yang signifikan maka dapat disimpulkan tidak adanya masalah heteroskedastisitas. Hasil pengujian heteroskedastisitas menunjukkan tidak terdapat pola yang jelas dari titik-titik tersebut. Hal ini menunjukkan bahwa model regresi tidak memiliki gejala adanya heteroskedastisitas.

\section{Hasil Pengujian Hipotesis}

\section{Pengujian Hipotesis 1}

Pengujian hipotesis secara parsial atau individu untuk masing-masing variabel melalui pengujian model substruktur kedua sebagai berikut:

Pengaruh income smoothing $\left(\mathrm{X}_{1}\right)$ terhadap kinerja keuangan $\left(\mathrm{Y}_{1}\right)$

Diperoleh nilai t hitung sebesar 1,217 dengan tingkat signifikan 0,228 berarti $\mathrm{t}_{\text {hitung }}(1,217)<\mathrm{t}_{\text {tabel }}(1,998)$ dan sig $(0,228)>\alpha(0,05)$ maka $\mathrm{H}_{\mathrm{a}}$ ditolak dan $\mathrm{H}_{0}$ diterima, sehingga dapat disimpulkan bahwa income smoothing $\left(\mathrm{X}_{1}\right)$ tidak berpengaruh signifikan terhadap kinerja keuangan $\left(\mathrm{Y}_{1}\right)$.

Pengaruh economic value added $\left(\mathrm{X}_{2}\right)$ terhadap kinerja keuangan $\left(\mathrm{Y}_{1}\right)$

Diperoleh nilai t hitung sebesar -0,946 dengan tingkat signifikan 0,348 berarti $\mathrm{t}_{\text {hitung }}(-0,946)<\mathrm{t}_{\text {tabel }}(1,998)$ dan sig $(0,348)>\alpha(0,05)$ maka $\mathrm{H}_{\mathrm{a}} \mathrm{H}_{\mathrm{a}}$ ditolak dan $\mathrm{H}_{0}$ diterima, sehingga dapat disimpulkan bahwa economic value added $\left(\mathrm{X}_{2}\right)$ tidak berpengaruh signifikan terhadap kinerja keuangan (Y1).

\section{Pengujian Hipotesis 2}

Dari hasil pengujian diperoleh nilai $\mathrm{F}_{\text {hitung }}$ sebesar 1,251 dengan tingkat signifikan 0,293 berarti $F_{\text {hitung }}(1,251)<\mathrm{F}$ tabel $(3,14)$ dan sig $(0,293)>\alpha(0,05)$ maka $\mathrm{H}_{\mathrm{a}}$ ditolak dan $\mathrm{H}_{0}$ diterima, sehingga dapat disimpulkan bahwa tidak terdapat pengaruh income smoothing dan economic value added yang signifikan secara simultan terhadap kinerja keuangan pada perusahaan manufaktur sektor barang konsumsi di Indonesia.

\section{Pengujian Hipotesis 3}

Pengujian hipotesis secara parsial atau individu untuk masing-masing variabel melalui pengujian model substruktur kedua sebagai berikut:

\section{Pengaruh income smoothing $\left(\mathrm{X}_{1}\right)$ terhadap nilai perusahaan $\left(\mathrm{Y}_{2}\right)$}

Diperoleh nilai t hitung sebesar -0,200 dengan tingkat signifikan 0,842 berarti $t_{\text {hitung }}(-0,200)$ terletak diantara $-t_{\text {tabel }}(-1,998)$ dan $t_{\text {tabel }}(1,998)$ dengan sig $(0,842)>\alpha(0,05)$ maka $\mathrm{H}_{a}$ ditolak dan $\mathrm{H}_{0}$ diterima, sehingga dapat disimpulkan bahwa income smoothing $\left(\mathrm{X}_{1}\right)$ tidak berpengaruh signifikan terhadap nilai perusahaan $\left(\mathrm{Y}_{2}\right)$.

Pengaruh economic value adde $\left(\mathrm{X}_{2}\right)$ terhadap nilai perusahaan $\left(\mathrm{Y}_{2}\right)$

Diperoleh nilai t hitung sebesar 1,658 dengan tingkat signifikan 0,102 berarti $t_{\text {hitung }}(1,528)$ terletak diantara $-t_{\text {tabel }}(-1,998)$ dan $t_{\text {tabel }}(1,998)$ dengan sig $(0,102)>\alpha(0,05)$ maka $\mathrm{H}_{\mathrm{a}}$ ditolak dan $\mathrm{H}_{0}$ diterima, sehingga dapat disimpulkan bahwa economic value adde $\left(\mathrm{X}_{2}\right)$ tidak berpengaruh signifikan terhadap nilai perusahaan $\left(\mathrm{Y}_{2}\right)$. 


\section{Pengujian Hipotesis 4}

Dari hasil pengujian diperoleh nilai $\mathrm{F}_{\text {hitung }}$ sebesar 1,416 dengan tingkat signifikan 0,250 berarti $\mathrm{F}$ hitung $(1,416)<\mathrm{F}$ tabel $(3,14)$ dan sig $(0,250)>\alpha(0,05)$ maka $\mathrm{H}_{\mathrm{a}}$ ditolak dan $\mathrm{H}_{0}$ diterima, sehingga dapat disimpulkan tidak terdapat pengaruh income smoothing dan economic value added yang signifikan secara simultan terhadap nilai perusahaan pada perusahaan manufaktur sektor barang konsumsi di Indonesia.

\section{Pengujian Hipotesis 5}

Diperoleh nilai t hitung sebesar 2,143 dengan tingkat signifikan 0,036 berarti $t_{\text {hitung }}(2,143)>t_{\text {tabel }}(1,998)$ dan sig $(0,036)<\alpha(0,05)$ maka $\mathrm{H}_{\mathrm{a}}$ diterima dan $\mathrm{H}_{0}$ ditolak, sehingga disimpulkan bahwa kinerja keuangan $\left(\mathrm{Y}_{1}\right)$ memiliki hubungan yang signifikan terhadap nilai perusahaan $\left(\mathrm{Y}_{2}\right)$.

\section{Pengujian Hipotesis 6}

Dari hasil pengujian diketahui korelasi atau hubungan antara income smmothing dan economic value added secara parsial terhadap nilai perusahaan melalui kinerja keuangan pada perusahaan manufaktur sektor barang konsumsi di Indonesia sebagai berikut:

a) Nilai korelasi antara income smoothing (X1) dengan nilai perusahaan (Y2) sebesar -0,035 dengan tingkat signifikansi 0,389 berarti terdapat hubungan yang tidak signifikan.

b) Nilai korelasi antara economic value added (X2) dengan nilai perusahaan (Y2) sebesar 0,049 dengan tingkat signifikansi 0,341 berarti terdapat hubungan yang tidak signifikan.

\section{Pengujian Hipotesis 7}

Berdasarkan output pengujian income smoothing dan economic value added terhadap nilai perusahaan melalui kinerja keuangan diperoleh dari :

Hubungan Income Smoothing dan Economic Value Added Secara Simultan Terhadap Kinerja Keuangan.

Nilai koefisien korelasi berganda (R) sebesar 0,195 dengan signifikansi 0,293 yang berarti terbukti terdapat hubungan dengan kriteria yang sangat lemah positif dan tidak signifikan. Sedangkan nilai koefisien determinasi (R square) sebesar 0,038 atau 3,8\% yang artinya variabel income smoothing dan economic value added mampu menjelaskan pengaruhnya terhadap perubahan variabel kinerja keuangan pada perusahaan manufaktur sektor barang konsumsi di Indonesia hanya sebesar $3.8 \%$ sedangkan sisanya sebesar $96,2 \%$ dijelaskan oleh variabel lainnya.

Hubungan Income Smoothing dan Economic Value Added Secara Simultan Terhadap Nilai Perusahaan.

Nilai koefisien korelasi berganda (R) sebesar 0,207 dengan signifikansi 0,250 yang berarti tidak terbukti terdapat hubungan dengan kriteria yang sangat lemah positif dan tidak signifikan. Sedangkan nilai koefisien determinasi (R square) sebesar 0,043 atau 4,3\% yang artinya variabel income smoothing dan economic value added mampu menjelaskan pengaruhnya terhadap perubahan 
variabel nilai perusahaan manufaktur sektor barang konsumsi di Indonesia secara bersama-sama sebesar $4,3 \%$ dan sisanya $95,7 \%$ dijelaskan oleh variabel lainnya.

\section{Pembahasan \\ Pembahasan Hasil Pengujian Hipotesis Pertama}

Pembahasan ini berkaitan dengan hasil pengujian terhadap hipotesis pertama yang menyatakan bahwa terdapat pengaruh income smoothing dan economic value added yang signifikan secara parsial terhadap kinerja keuangan pada perusahaan manufaktur sektor barang konsumsi di Indonesia. Hasil penelitian menunjukkan bahwa kedua variabel baik income smoothing ataupu economic value added tidak ada yang berpengaruh terhadap kinerja keuangan. Dari hasil pengolahan data menunjukkan bahwa $86,3 \%$ perusahaan yang dijadikan sampel penelitian tidak melakukan tindakan perataan laba, tetapi meskipun perusahaan tersebut tidak melakukan tindakan perataan laba harga pasar saham yang berlaku sangat tinggi. Berdasar hasil pengolahan data diperoleh bahwa meskipun EVA perusahaanperusahaan yang dijadikan sampel penelitian hasilnya negatif, tetapi hal ini tidak berpengaruh terhadap harga pasar saham masing-masing perusahaan. Seharusnya kinerja yang baik itu ditandai oleh hasil EVA yang positif. kebanyakan perusahaan-perusahaan ini EVA nya rata-rata negatif, tetapi harga pasar saham rata-rata tinggi.

\section{Pembahasan Hasil Pengujian Hipotesis Kedua}

Pembahasan ini berkaitan dengan hasil pengujian terhadap hipotesis kedua yang menyatakan bahwa terdapat pengaruh income smoothing dan economic value added yang signifikan secara simultan terhadap kinerja keuangan pada perusahaan manufaktur sektor barang konsumsi di Indonesia. Hasil penelitian menunjukkan bahwa income smoothing dan economic value added secara simultan tidak berpengaruh signifikan terhadap kinerja keuangan. Ternyata tanpa melakukan income smoothing dan EVA yang dihasilkan negatif, harga saham perusahaan ini masih tinggi, artinya para investor masih percaya pada kinerja keuangan perusahaan manufaktur sektor barang konsumsi yang terdaftar di Bursa Efek Indonesa

\section{Pembahasan Hasil Pengujian Hipotesis Ketiga}

Pembahasan ini berkaitan dengan hasil pengujian terhadap hipotesis ketiga yang menyatakan bahwa terdapat pengaruh income smoothing dan economic value added yang signifikan secara parsial terhadap nilai perusahaan pada perusahaan manufaktur sektor barang konsumsi di Indonesia. Hasil penelitian menunjukkan bahwa kedua variabel baik income smoothing maupun economic value added secara parsial tidak berpengaruh signifikan terhadap nilai perusahaan. Setelah diadakan olah data ternyata banyak perusahaan tidak melakukan tindakan perataan laba. Rata-rata hasil perhitungan EVA hasilnya negatif tetapi meskipun begitu harga saham perusahaan-perusahaan tersebut tetap tinggi dan dipercaya oleh investor hal tersebut dibuktikan oleh jumlah ekuitas perusahaan tersebut lebih tinggi dibanding nilai hutangnya. 


\section{Pembahasan Hasil Pengujian Hipotesis Keempat}

Pembahasan ini berkaitan dengan hasil pengujian terhadap hipotesis keempat yang menyatakan bahwa terdapat pengaruh income smoothing dan economic value added yang signifikan secara simultan terhadap nilai perusahaan pada perusahaan manufaktur sektor barang konsumsi di Indonesia. Hasil penelitian menunjukkan bahwa variabel income smoothing dan economic value added secara bersama-sama tidak berpengaruh signifikan terhadap nilai perusahaan. Nilai perusahaan hanya ditentukan oleh kemampuan menghasilkan laba, income smoothing dan EVA bukan kegiatan menghasilkan laba tetapi memanajemen laba dan upaya untuk mensejahterakan pemegang saham dan kreditur.

\section{Pembahasan Hasil Pengujian Hipotesis Kelima}

Pembahasan ini berkaitan dengan hasil pengujian terhadap hipotesis kelima yang menyatakan bahwa terdapat hubungan kinerja keuangan yang signifikan terhadap nilai perusahaan pada perusahaan manufaktur sektor barang konsumsi di Indonesia. Hasil penelitian menunjukkan bahwa kinerja keuangan memiliki hubungan positif yang signifikan terhadap nilai perusahaan, artinya semakin tinggi kinerja keuangan maka semakin tinggi pula nilai perusahaan dan sebaliknya. Kinerja keuangan yang diwakili oleh return on asset, return on asset adalah kemampuan perusahaan menghasilkan laba dengan didasarkan pada total aset. Nilai perusahaan hanya ditentukan oleh kemampuan menghasilkan laba, ROA berkaitan dengan menghasilkan laba yang dihubungkan dengan besarnya total aset yang dimiliki perusahaan.

\section{Pembahasan Hasil Pengujian Hipotesis Keenam}

Pembahasan ini berkaitan dengan hasil pengujian terhadap hipotesis keenam yang menyatakan bahwa terdapat hubungan income smoothing dan economic value added yang signifikan secara parsial terhadap nilai perusahaan melalui kinerja keuangan pada perusahaan manufaktur sektor barang konsumsi di Indonesia. Hasil penelitian menunjukkan bahwa secara parsial variabel income smoothing dan economic value added tidak memiliki hubungan yang signifikan terhadap nilai perusahaan melalui kinerja keuangan. Hal tersebut dibuktikan pengaruh income smoothing dan economic value added baik secara parsial maupun simultan tidak berpengaruh terhadap baik kinerja keuangan maupun nilai perusahaan.

\section{Pembahasan Hasil Pengujian Hipotesis Ketujuh}

Pembahasan ini berkaitan dengan hasil pengujian terhadap hipotesis ketujuh yang menyatakan bahwa terdapat hubungan income smoothing dan economic value added yang signifikan secara simultan terhadap nilai perusahaan melalui kinerja keuangan pada perusahaan manufaktur sektor barang konsumsi di Indonesia. Hasil penelitian menunjukkan bahwa income smoothing dan economic value added secara simultan tidak memiliki hubungan dengan nilai perusahaan melalui kinerja keuangan.Hubungan antara income smoothing dan economic value added terhadap nilai perusahaan melalui kinerja keuangan dibuktikan dengan pengaruh secara total yang nilainya menunjukkan hubungan tersebut sangat lemah dan tidak signifikan. Berdasar nilai $\mathrm{R}$ square juga menunjukkan nilai yang sangat rendah 
yakni sebesar 3\% dan 4\% sedangkan sisanya sebesar 96\% dan 97\% dipengaruhi variabel lain yang tidak diteliti pada penelitian. Hal tersebut disebabkan karena perusahaan yang diteliti adalah perusahaan yang menurut beberapa investor mampu mensejahterakan kepentingan mereka, tidak sama jenisnya dan tahun yang diteliti terlalu sedikit yakni hanya 3 (tiga) tahun.

\section{KESIMPULAN}

Berdasarkan hasil penelitian dan pembahasan yang telah diuraikan di atas, maka dapat diambil beberapa kesimpulan sebagai berikut:

a. Hasil pengujian terhadap hipotesis pertama yang menyatakan bahwa terdapat pengaruh income smoothing dan economic value added yang signifikan secara parsial terhadap kinerja keuangan pada perusahaan manufaktur sektor barang konsumsi di Indonesia. Hasil penelitian menunjukkan bahwa kedua variabel baik income smoothing ataupun economic value added tidak ada yang berpengaruh terhadap kinerja keuangan.

b. Hasil pengujian terhadap hipotesis kedua yang menyatakan bahwa terdapat pengaruh income smoothing dan economic value added yang signifikan secara simultan terhadap kinerja keuangan pada perusahaan manufaktur sektor barang konsumsi di Indonesia. Hasil penelitian menunjukkan bahwa income smoothing dan economic value added secara simultan tidak berpengaruh signifikan terhadap kinerja keuangan.

c. Hasil pengujian terhadap hipotesis ketiga yang menyatakan bahwa terdapat pengaruh income smoothing dan economic value added yang signifikan secara parsial terhadap nilai perusahaan pada perusahaan manufaktur sektor barang konsumsi di Indonesia. Hasil penelitian menunjukkan bahwa kedua variabel baik income smoothing maupun economic value added secara parsial tidak berpengaruh signifikan terhadap nilai perusahaan.

d. Hasil pengujian terhadap hipotesis keempat yang menyatakan bahwa terdapat pengaruh income smoothing dan economic value added yang signifikan secara simultan terhadap nilai perusahaan pada perusahaan manufaktur sektor barang konsumsi di Indonesia. Hasil penelitian menunjukkan bahwa variabel income smoothing dan economic value added secara bersama-sama tidak berpengaruh signifikan terhadap nilai perusahaan.

e. Hasil pengujian terhadap hipotesis kelima yang menyatakan bahwa terdapat hubungan kinerja keuangan yang signifikan terhadap nilai perusahaan pada perusahaan manufaktur sektor barang konsumsi di Indonesia. Hasil penelitian menunjukkan bahwa kinerja keuangan memiliki hubungan positif yang signifikan terhadap nilai perusahaan

f. Hasil pengujian terhadap hipotesis keenam yang menyatakan bahwa terdapat hubungan income smoothing dan economic value added yang signifikan secara parsial terhadap nilai perusahaan melalui kinerja keuangan pada perusahaan manufaktur sektor barang konsumsi di Indonesia. Hasil penelitian menunjukkan bahwa secara parsial variabel income smoothing dan economic value added tidak memiliki hubungan yang signifikan terhadap nilai perusahaan melalui kinerja keuangan. 
g. Hasil pengujian terhadap hipotesis ketujuh yang menyatakan bahwa terdapat hubungan income smoothing dan economic value added yang signifikan secara simultan terhadap nilai perusahaan melalui kinerja keuangan pada perusahaan manufaktur sektor barang konsumsi di Indonesia. Hasil penelitian menunjukkan bahwa income smoothing dan economic value added secara simultan tidak memiliki hubungan dengan nilai perusahaan melalui kinerja keuangan.

\section{DAFTAR PUSTAKA}

Aji dan Mita, 2010, Pengaruh Profitabilitas, Risiko Keuangan, Nilai Perusahaan dan Struktur Kepemilikan Terhadap Praktek Perataan Laba; Studi Empiris Perusahaan Manufaktur yang Terdaftar di BEI.

Andrie Putra dan Royhisar Martahan Simanungkalit, 2014, The Impact of Implementation Good Corporate Governance to Firm Value (Evidence from Indonesia Public Banking Sector), Review Integrative Business \& Economics Research, Vol 4(1).

Amin Widjaya Tunggal, 2001, Memahami Konsep Economic Value Added (EVA) dan Value Based Management (VBM), Harvarindo.

Atik Agustiningsih. 2008. Analisis Cash Ratio, Loan To Deposito Ratio (LDR), dan Loan Total Asset Ratio (LAR) Untuk mengukur tingkat Likuiditas Perbankan (Studi Empiris Pada Perusahaan Perbankan Yang terdaftar di Bursa Efek Indonesia, Universitas Muhammadiyah Surakarta.

Beidleman, C, 1973, Income Smoothing: The Role of Management, The Accounting Review, October 1973, p. 653-668.

Efendi Pakpahan, 2013, Pengertian Economic Value Added, tugasakhiramik.blogspot.co.id

Fahmi Nugraha dan Muhammad Doddy A. Bahtiar, 2012. Pengaruh Return On Equity dan Economic Value Added Terhadap Nilai Perusahaan (Studi Kasus Pada Perusahaan Yang Menerbitkan Saham Dalam Daftar Efek Syariah), Jurnal Akuntansi dan Keuangan Islam.

Harjito, A dan Martono. 2005. Manajemen Keuangan. Yogyakarta.

Hijah Maisyarah, dkk, 2017, Pengaruh Manajemen Laba Dan Kinerja Keuangan Terhadap Nilai Perusahaan, Malang

I Putu AdnyanaUshada dan Gerianta Wirawan Yasa, 2010, Analisis Manajemen Laba Dan Kinerja Keuangan Perusahaan Pengakuisisi Sebelum dan 
Sesudah Merger dan akuisisi Di Bursa Efek Indonesia, Fakultas Ekonomi Universitas Udayana.

Keown et al. 2005. Manajemen Keuangan (prinsip-prinsip dan aplikasi). Jakarta Barat: PT indeks kelompok Gramedia.

Mohammad Reza Shourvarzi and Sahar Sadeddin, 2011, Analysis of The Predictive Ability of The Components of Economic Value added in Predicting Next Period's Operating Profit: Evidence From Iran, African Journal of Business Management Vol. 5 (8), 18 April 2011.

Munawir, 2010, Analisa Laporan Keuangan, Edisi 4. Liberty, Yogyakarta.

Nora Alverniatha dan Samuel Dossugi, 2012, Analisis Perbandingan Economic Value Added (EVA) Dan Financial Value Added (FVA) sebagai alat Ukur Penilaian Kinerja Keuangan Pada Industri Perkebunan Di Bursa Efek Indonesia, Journal of Applied Finance and Accounting, hal 75-93

Novita. 2009. Pengaruh Faktor Finansial Perusahaan Terhadap Praktik Perataan Laba (Income Smoothing) Pada Perusahaan Manufaktur Yang Terdaftar di BEI (Periode Tahun 2005-2007).

Prof. Dr. Abdul Ghafoor Awan, et al., 2014, The Effect Of Economic Value Added On Stock Return: Evidence From Selected Companies Of Karachi Stock Exchange, Research Journal of Finance and Accounting, Vol. 5, No. 23, 2014, Pakistan.

Scott, W. R. 2006. Financial Accounting Theory. 4th ed. Toronto: Prentice-Hall.

Sri Sulistyanto, 2008, Manajemen Laba Teori dan Model Empiris, Grasindo, Jakarta

Widayanto, G., 1993, EVA/NITAMI: Suatu Terobosan Baru dalam Pengukuran Kinerja Perusahaan, No.12, Desember 1993, Manajemen Usahawan Indonesia No. 4 Th. XXII.

Young, S, David dan O'Byrne, F. Stepheh, 2009, EVA dan Manajemen Berdasarkan Nilai, Salemba Empat, Jakarta.

Ajanthan, A. (2013). Impact of Corporate Governance Practices on Firm Capital Structure and Profitability: A Study of Selected Hotels and Restaurant Companies in Sri Lanka. Research Journal of Finance and Accounting, 4(10), 2222-2847. Retrieved from http://ssrn.com/abstract=2381183

Ato'Illah, M. (2014). Analisis Pengaruh Gaya Kepemimpinan dan Motivasi Terhadap Kinerja Pegawai Kelurahan di Kecamatan Lumajang Kabupaten 
Lumajang. WIGA-Jurnal Penelitian Ilmu Ekonomi, 4(1), 1-18.

Budiwati, H., \& Jariah, A. (2014). Penggunaan Rasio Keuangan CAMEL Untuk Memprediksi Kepailitan Dengan Discriminant Analysis Models Z Score (Studi Kasus Pada Bank Perkreditan Rakyat di Indonesia). WIGA-Jurnal Penelitian Ilmu Ekonomi, 4(2), 17-27.

Ermawati, E. (2017). PENGARUH KONTRAK PSIKOLOGIS DAN KOMITMEN ORGANISASI TERHADAP KINERJA KARYAWAN DI KLINIK HUSADA MULIA KABUPATEN LUMAJANG. ASSETS-Jurnal Ilmiah Ilmu Akuntansi, Keuangan Dan Pajak, 1(2), 141-160.

Fauziah, A., \& Psikolingui, K. (n.d.). KAJIAN PSIKOLINGUISTI.

Ifa, K. (2017). Kontribusi Pajak Daerah Dan Retribusi Daerah Terhadap Pendapatan Asli Daerah (PAD) Di Kabupaten Jember. ASSETS-Jurnal Ilmiah Ilmu Akuntansi, Keuangan Dan Pajak, 1(2), 69-81.

Iridiana, S. (2016). Analisis Faktor-faktor Yang Mempengaruhi Strukturmodal Pada Perusahaan Katagori Saham Blue Chips Di Bursa Efek Indonesia Periode Tahun 2011-2014. WIGA-Jurnal Penelitian Ilmu Ekonomi, 6(1), 1526.

Irwanto, J. (2017). PENGARUH STORE ATMOSPHERE, LOKASI, DAN KERAGAMAN PRODUK TERHADAP KEPUTUSAN PEMBELIAN PAKAIAN PADA PASAR UMUM PASIRIAN LUMAJANG. Jurnal Ilmu Manajemen Advantage, 1(1).

Jariah, A. (2012). Analisis faktor-faktor pribadi yang mempengaruhi keputusan pembelian sepeda motor Yamaha di lumajang. WIGA-Jurnal Penelitian Ilmu Ekonomi, 2(2).

Kumar, J. K. (2004). Agency Theory and Firm Value in India. SSRN Electronic Journal. https://doi.org/10.2139/ssrn.501802

Lukiana, N. (2014). STRUKTUR MODAL DIPENGARUHI OLEH BEBAN PAJAK, RISIKO BISNIS, DAN STRUKTUR KEPEMILIKAN (Studi pada Perusahaan Manufaktur yang Listed di Bursa Efek Indonesia Periode 20092012). WIGA-Jurnal Penelitian Ilmu Ekonomi, 4(2), 28-38.

Nawangsih, N. (2017). NILAI KEARIFAN LOKAL KAWASAN WISATA MENGGUNAKAN PENDEKATANGREEN MARKETING BERBASIS MASYARAKAT. WIGA-Jurnal Penelitian Ilmu Ekonomi, 7(1), 57-65.

Paramita, R. W. D. (2012). PENGARUH FIRM SIZE TERHADAP EARNINGS RESPONSE COEFFISIENT (ERC) DENGAN VOLUNTARY DISCLOUSURE SEBAGAI VARIABEL INTERVENING (Studi Pada 
Perusahaan Manufaktur Yang Terdaftar Di Bursa Efek Indonesia). WIGAJurnal Penelitian Ilmu Ekonomi, 2(1).

Robustin, T. P. (2015). PENGARUH AUGMENTED PRODUCT TERHADAP KEPUASAN DAN LOYALITAS KONSUMEN DALAM MEMBELI MOTOR YAMAHA MIO DI DEALER KENCONG JAYA MOTOR. Jurnal Bisnis Dan Manajemen, 9(1), 1-16.

Yatminiwati, M. (2017). Implementasi Pengelolaan Dan Penatausahaan Keuangan Desa Berdasarkan Permendagri No. 113 Th. 2014 Tentang Pengelolaan Keuangan Desa. ASSETS: Jurnal Ilmiah Ilmu Akuntansi, Keuangan Dan Pajak, 1(1). 